


\section{Editorial Committee}

Su-Hie TING

Ai-Ping $\mathrm{HO}$

Collin JEROME

Hamidah ABDUL WAHAB

Wan Robiah MEOR OSMAN

Wun-Chiew PUNG

Cover Design: Nur Shazwanie WAKIMIN

(C) 2021 Universiti Malaysia Sarawak

94300 Kota Samarahan

Sarawak, Malaysia

All rights reserved; no part of this publication may be reproduced, stored or transmitted in any form or by any means without prior written permission of the copyright holder.

The proceedings have been edited for format and layout, but content and language errors remain the responsibility of the author(s). The proceedings is not refereed. Papers which fall too far from specified requirements could not be included in the proceedings. For further details, visit http://www.conference.unimas.my/2021/icls2021/

The proceedings are available at http://www.conference.unimas.my/2021/icls2021/index.php/programme/icl s2021-proceedings

- Associate Professor Dr Su-Hie Ting -

National Library of Malaysia Cataloguing in Publication Data

e ISBN 978-967-2298-69-4

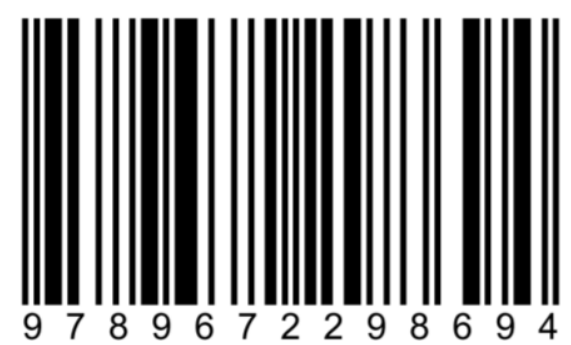




\title{
SIKAP BAHASA DAN PEMERTAHANAN IDENTITI KOMUNITI SEMPADAN DI KAMPUNG TELOK MELANO, MALAYSIA DAN DESA TEMAJUK, INDONESIA: SATU TINJAUAN AWAL \\ Dilah TUAH*1 \\ Shin CHONG² \\ ${ }^{1}$ Fakulti Bahasa \& Komunikasi, Universiti Malaysia Sarawak \\ ${ }^{2}$ Institut Alam \& Tamadun Melayu, Universiti Kebangsaan Malaysia \\ 1tdilah@unimas.my \\ ²hongshin@ukm.edu.my
}

${ }^{*}$ Corresponding author

\begin{abstract}
ABSTRAK
Kajian ini meneliti sikap bahasa dan pemertahanan identiti komuniti sempadan di Kampung Telok Melano, Lundu (Sarawak, Malaysia) dan Desa Temajuk, Sambas (Kalimantan Barat, Indonesia). Objektif khusus kajian adalah untuk meninjau sikap bahasa dan penjelmaan identiti melalui bahasa, yang akhirnya membentuk dua identiti yang berbeza. Pengumpulan data kajian berasaskan pendekatan kualitatif iaitu melalui rakaman perbualan, wawancara dan pemerhatian ikut serta. Dalam kajian awal ini, seramai 12 orang informan iaitu 6 orang dari Kampung Telok Melano dan 6 orang dari Desa Temajuk telah dipilih berdasarkan kaedah pensampelan kuota. Soalan wawancara dirangka mengikut beberapa domain daripada tiga ciri sikap bahasa yang dikemukakan oleh Garvin \& Mathiot (1968) iaitu kesetiaan bahasa, kebanggaan bahasa dan kesedaran akan norma bahasa. Dapatan kajian menunjukkan kesetiaan bahasa, kebanggaan bahasa dan kesedaran akan norma bahasa, khususnya terhadap bahasa ibunda dan bahasa kebangsaan adalah tinggi dalam kalangan kedua-dua komuniti yang dikaji. Dari aspek pemertahanan identiti, kajian mendapati masyarakat di Kampung Telok Melano yang asalnya beridentitikan 'Melayu Sambas', telah beralih menjadi 'Melayu Sarawak' sejak pembentukan Malaysia pada tahun 1963. Kajian awal ini telah menyediakan asas penyelidikan untuk kajian lanjutan pada masa hadapan berkaitan dengan isu bahasa dan identiti masyarakat sempadan di bahagian barat daya Sarawak.
\end{abstract}

Kata Kunci: sikap bahasa, identiti, komuniti sempadan, sosiolinguistik, Telok Melano, Temajuk

LANGUAGE ATTITUDE AND THE DEFENCE OF THE BORDER COMMUNITY IDENTITY AT KAMPUNG TELOK MELANO, MALAYSIA AND DESA TEMAJUK, INDONESIA: A

PRELIMINARY STUDY 